Aminah Asngad, Risky Amella, Nurul Aeni. (2018). Pemanfaatan Kombinasi Kulit Kacang dengan Bonggol Pisang dan Biji Nangka untuk Pembuatan Plastik Biodegradable dengan Penambahan Gliserol. Jurnal Bioeksperimen. Vol. 4 (1) Pp. 11-19. Doi: https://doi.org/10.23917/bioeksperimen.v4i1.5572

\title{
Pemanfaatan Kombinasi Kulit Kacang dengan Bonggol Pisang dan Biji Nangka untuk Pembuatan Plastik Biodegradable dengan Penambahan Gliserol
}

\author{
Aminah Asngad*, Risky Amella, Nurul Aeni \\ Pendidikan Biologi FKIP Universitas Muhammdiyah Surakarta \\ Jalan A. Yani Pabelan Kartasura Tromol Pos I Surakarta Jawa Tengah \\ *Email : aa125@ums.ac.id
}

\begin{abstract}
ABSTRAK
Untuk menyelamatkan lingkungan dari bahaya plastik, saat ini telah dikembangkan plastik biodegradable yang dapat diuraikan kembali oleh mikroorganisme secara alami menjadi senyawa yang ramah lingkungan. Tujuan penelitian ini Untuk mengetahui ketahanan tarik dan perpanjangan putus serta uji biodegradabel plastik dari kulit kacang dengan bonggol pisang dan biji nangka dengan penambahan gliserol. Penelitian dilakukan di lab.Biologi FKIP UMS, metode penelitian eksperimen. Rancangan penelitian acak lengkap dengan 2 faktor perlakuan yaitu: Faktor 1 kombinasi perlakuan $(K), K_{1}$ = kacang tanah dan bonggol pisang; $K_{2}=$ kacang tanah dan biji nangka. Faktor 2 kadar gliserol $(G), G_{1}=6 m l ; G_{2}=$ $7 \mathrm{ml} ; G_{3}=8 \mathrm{ml}$. Analisis yang digunakan deskriptif kualitatif untuk uji ketahanan tarik, perpanjangan putus dan uji biodegradabilitas. Hasil penelitian menunjukkan ketahanan tarik paling kuat, $K_{1} G_{1}$ yakni $1.38 \mathrm{~N} / \mathrm{mm}^{2}$, paling rendah $K_{2} G_{3}$ yakni $0.66 \mathrm{~N} / \mathrm{mm}^{2}$. Perpanjangan putus paling tinggi, $K_{1} G_{3}$ yakni $21.05 \mathrm{~N} / \mathrm{mm}^{2}$, paling rendah $K_{2} G_{1}$ yakni 17.44 $\mathrm{N} / \mathrm{mm}^{2}$. Pada $K_{1} G_{3}$ memiliki nilai rata-rata biodegradabilitas yang paling tinggi, yaitu $90.38 \%$ sedangkan $K_{2} G_{1}$ yang paling rendah yaitu 58,84\%. Berdasarkan hasil penelitian dapat diambil simpulan ada perbedaan ketahanan tarik dan perpanjangan putus serta hasil uji biodegradabilitas plastik biodegradable dari kulit kacang dengan bonggol pisang dan biji nangka dengan penambahan gliserol.
\end{abstract}

Kata Kunci: ketahanan tarik, perpanjangan putus, uji biodegradable, kulit kacang dengan bonggol pisang dan kulit kacang dengan biji nangka.

\section{Pendahuluan}

Plastik merupakan bahan yang relatif nondegradable sehingga pemanfaatan plastik harus diperhatikan mengingat besarnya limbah yang dihasilkannya. Plastik merupakan material yang baru secara luas dikembangkan dan digunakan sejak abad ke-20 yang berkembang secara luar biasa penggunaannya dari hanya beberapa ratus ton pada tahun 1930-an, menjadi 150 juta ton/tahun pada tahun 1990-an dan 220 juta ton/tahun pada tahun 2005.

Plastik yang beredar di pasaran saat ini merupakan polimersintetikyang terbuat dari minyak bumi yang sulit untuk terurai di alam. Akibatnya semakin banyak yang menggunakan plastik, akan semakin meningkat pula pencemaran lingkungan seperti penurunan kualitas air dan tanah menjadi tidak subur. Untuk menyelamatkan lingkungan dari bahaya plastik, saat ini telah dikembangkan plastik biodegradable, artinya plastik ini dapat diuraikan kembali oleh mikroorganisme secara alami menjadi senyawa yang ramah lingkungan. Biasanya plastik konvensional berbahan dasar petroleum, gas alam, atau batu bara. Sementara plastik biodegradable terbuat dari material yang dapat diperbaharui, yaitu dari senyawa-senyawa yang terdapat dalam tanaman misalnya selulosa, kolagen, kasein, protein.

Jenis plastik biodegradable antara lain polyhidroksialkanoat (PHA) dan poli-asam amino yang berasal dari sel bakteri, polylaktida (PLA) yang merupakan modifikasi asam laktat hasil perubahan zat tepung kentang atau jagung oleh mikroorganisme, dan poliaspartat sintesis yang dapat terdegradasi. Bahan dasar plastik berasal dari selulosa bakteri, kitin, kitosan, atau tepung yang terkandung dalam tumbuhan, serta beberapa material plastik atau polimer lain yang terdapat di sel tumbuhan dan 
hewan. Plastik biodegradable berbahan dasar tepung dapat didegradasi bakteri Pseudomonas dan Bacillus memutus rantai polimer menjadi monomermonomernya. Senyawa-senyawa hasil degradasi polimer selain menghasilkan karbon dioksida dan air, juga menghasilkan senyawa organik lain yaitu asam organik dan aldehid yang tidak berbahaya bagi lingkungan. Plastik berbahan dasar tepung aman bagi lingkungan, sebagai perbandingan, plastik tradisional membutuhkan waktu sekira 50 tahun agar dapat terdekomposisi alam, sementara plastik biodegradable dapat terdekomposisi 10 hingga 20 kali lebih cepat.

Hasil degradasi plastik ini dapat digunakan sebagai makanan hewan ternak atau sebagai pupuk kompos. Plastik biodegradable yang terbakar tidak menghasilkan senyawa kimia berbahaya. Kualitas tanah akan meningkat dengan adanya plastik biodegradable, karena hasil penguraian mikroorganisme meningkatkan unsur hara dalam tanah. Sampaisaatini masih diteliti berapa kecepatan atau berapa banyak polimer biodegradable ini dapat diuraikan alam. Di samping itu, penambahan tepung pada pembuatan polimer biodegradabletidak menambah biaya pembuatan plastik.

Hal ini tentu bisa menjadi sebuah potensi yang besar di Indonesia, karena terdapat berbagai tanaman penghasil tepung seperti singkong, beras, kentang, dan tanaman lainnya. Apalagi harga umbi-umbian di Indonesia relatif rendah. Dengan memanfaatkan sebagai bahan plastik biodegradable, akan memberi nilai tambah ekonomi yang tinggi. Penelitian lebih lanjut sangat diperlukan. Akan tetapi penggunaan plastik biodegradable di Indonesia masih jarang. Padahal jelas sekali, bahwa potensi bahan baku pembuatan plastik biodegradable sangat besar di Indonesia. Tampaknya perlu dukungan dari semua pihak terutama pemerintah selaku regulator, industri kimia dan proses, serta kesadaran dari seluruh masyarakat. Harus ada kerja sama di antara banyak pihak untuk mendukung penerapan plastik biodegradable menggantikan plastik konvensional.

Sejauh ini, pemanfaatan kacang tanah masih terbatas pada pengolahan bijinya saja yang kemudian diolah menjadi produk makanan ringan atau bumbu masakan. Sementara itu, kulitnya belum dimanfaatkan secara maksimal. Kulit kacang tanah umumnya hanya menjadi limbah atau sebagai pakan ternak dan sebagai bahan dasar pembuatan asap cair (liquid smoke) antioksidan (Pertiwi, 2011), briket untuk bahan bakar alternatif (Eko, 2010), dan pupuk organik (Dahlan dan Darmansyah, 2011).

Sekitar 30\% dari buah kacang tanah berupa kulit dengan kandungan serat selulosa pada kulit kacang tanah sebesar 63,5\% (Murni, 2008).

Berdasarkan data BPS pada tahun 2012, jumlah kacang tanah yang dipasok ke industri kacang tanah di Kabupaten Pati adalah 212.949,72 ton. Jika 30\% dari kacang tanah berupa kulit, maka dengan produksi tersebut akan dihasilkan limbah kulit kacang tanah sekitar 63.884,92 ton. Limbah kulit kacang tanah dengan jumlah tersebut merupakan jumlah yang cukup besar dengan kandungan selulosa yang tinggi. Menurut hasil penelitian Asngad Aminah dkk (2014) bahwa pada ketahanan tarik dan ketahanan sobek pada pembuatan kertas, perlakuan yang paling tinggi ketahanan tariknya dan ketahanan sobeknya adalah 50\% limbah bulu ayam:50\% limbah kulit kacang tanah.

Penambahan selulosa pada pembuatan plastik biodegradabel dapat menambah sifat fisik dan mekanik pada plastik biodegradabel. Berdasrkan penelitian Septiosari (2014) nilai kuat tarik plastik biodegradabel dari pati dan selulosa serbuk kayu gergaji, antara pati-selulosa (8:2)-gliserol 15\% lebih besar dibandingkan dengan pati-aquades (1:20)-gliserol 15\%. Hasil kuat tarik terbaik pada penggunaan pati-selulosa (8:2)-gliserol 15\% yaitu sebesar 6,2551 Mpa dengan daya elongasi sebesar $13,43 \%$ dan perkiraan waktu terdegradasi selama 26 hari. Selain pada serbuk kayu gergaji selulosa juga terdapat pada kulit kacang tanah.

Bonggol pisang merupakan limbah dari hasil panen tanaman pisang yang mengandung pati cukup tinggi. Kandungan pati di setiap varietas bonggol pisang berbeda, misalnya pada bonggol pisang mas mengandung $67,80 \%$ pati dan bonggol pisang kepok mengandung pati sebanyak $64,20 \%$ (Asni, 2015). Berdasarkan penelitian Pratiwi (2016) pembuatan plastik yang mudah terdegradasi dari pati bonggol pisang kepok dengan perbandingan pati sebanyak 10 gram dan aquades sebanyak $200 \mathrm{~mL}$ dengan variasi volume gliserol $3 \mathrm{~mL} ; 3,5$ $\mathrm{mL} ; 4 \mathrm{~mL} ; 4,5 \mathrm{~mL}$ dan $5 \mathrm{~mL}$ menghasilkan nilai biodegradasi tertinggi pada penggunaan gliserol $4 \mathrm{~mL}$ yaitu plastik yang terdegradasi dari pati 
bonggol pisang kepok adalah sebesar 93.45\% . Kemampuan degradasi suatu plastik berkaitan dengan kemampuan menyerap air yang dipengaruhi oleh banyaknya gliserol.

Biji buah nangka yang keberadaannya sangat melimpah belum banyak dimanfaatkan atau hanya dibuang begitu saja meskipun kandungan patinya cukup tinggi, hal tersebut dikarenakan biji buah nangka bukan termasuk bahan utama makanan pokok pengganti pati (Anggraini, 2013). Pati biji buah nangka mengandung amilosa sebesar 39,23\% (Mukprasit, 2004). Berdasarkan hasil penelitian Anggraini (2013) formulasi terbaik dihasilkan oleh campuran pati-aquades-gliserol 20\% menghasilkan plastik dengan nilai kuat tarik sebesar 58,83 $\mathrm{MPa}$, elongasi $22,5 \%$, hidrofobisitas $79,02 \%$, dan terdegradasi $54 \%$ dalam waktu 6 hari dengan degradabilitas 7,4 mg/hari. Selain pati, pembuatan bioplastik juga diperlukan penambahan selulosa dan gliserol untuk menghasilkan bioplastik terbaik (Septiosari, 2014).

Pada proses pembuatan plastik ramah lingkungan (biodegradable) perlu ditambahkan plasticizer agar plastik yang dihasilkan lebih elastis, fleksibel, dan tahan terhadap air (Darni, dkk. 2008). Penambahan ini bertujuan untuk memperbaiki sifat fisik, sifat mekanik dan melindungi plastik dari mikroorganisme yang dapat merusak plastik. Salah satu plasticizer yang banyak digunakan dalam pembuatan plastik ramah lingkungan (biodegradable) adalah gliserol. Hal ini dikarenakan gliserol sebagai plasticizer dapat memberikan sifat yang lebih elastis terhadap plastik jika dibandingkan plasticizer lain, seperti sorbitol (Paramawati, 2001). Gliserol termasuk senyawa yang banyak ditemui di alam dan harganya relatif murah. Selain itu, gliserol bersifat ramah lingkungan, karena senyawa ini dengan mudah dapat terdegradasi oleh mikroorganisme (Marhanah, 2008).

Berdasarkan dari beberapa permasalahan tersebut, maka peneliti akan melakukan penelitian tentang pemanfaatan kombinasi kulit kacang dengan bonggol pisang dan biji nangka untuk pembuatan plastik biodegfradabel dengan penambahan gliserol.

Berdasarkan latar belakang di atas maka yang menjadi permasalahan dalam penelitian ini adalah 1). Bagaimana ketahanan tarik dan perpanjangan putus plastik biodegradable dari kulit kacang dengan bonggol pisang dan biji nangka dengan penambahan gliserol? 2). Bagaimana uji biodegradabilitas plastik biodegradable dari kulit kacang dengan bonggol pisang dan biji nangka dengan penambahan gliserol?

Adapun tujuan yang akan dicapai pada penelitian ini adalah untuk mengetahui 1). Untuk mengetahui ketahanan tarik dan perpanjangan putus plastik biodegradable dari kulit kacang dengan bonggol pisang dan biji nangka dengan penambahan gliserol, 2). Untuk mengetahui sifat organoleptik (tekstur) plastik biodegradable dari kulit kacang dengan bonggol pisang dan biji nangka dengan penambahan gliserol.

\section{Metode Penelitian}

Penelitian telah dilaksanakan pada bulan Februari-Oktober 2017 diLaboratorium BiokimiaProdi Pend. Biologi UMS, dan Laboratorium Uji dan Kalibrasi Balai Besar Karet, Kulit, dan Plastik Yogyakarta. Metode penelitian yang digunakan adalah metode penelitian eksperimental. Rancangan lingkungan yang digunakan rancangan acak lengkap (RAL) dengan pola faktorial dan dua ulangan. Penelitian digunakan 2 faktor, yaitu:

Faktor perlakuan 1 kombinasi perlakuan (K)

$\mathrm{K}_{1}$ = kacang tanah dan bonggol pisang

$\mathrm{K}_{2}=$ kacang tanah dan biji nangka

Faktor perlakuan 2 kadar gliserol (G)

$\mathrm{G}_{1}=6 \mathrm{ml}$

$\mathrm{G}_{2}=7 \mathrm{ml}$

$\mathrm{G} 3=8 \mathrm{ml}$

Adapun Prosedur Penelitian meliputi: a). Tahap persiapan, b). Tahap pelaksanaan pembuatan plastik biodegradable, c). Tahap pengujian uji ketahanan tarik, uji perpanjangan putus dengan menggunakan alat universal testing machine dan dan uji biodegradabilitas dengan mengeringkan plastik dalam desikator kemudian mengubur sampel dalam tanah selama \pm 2 minggu.

Dalam penelitian ini, analisis yang digunakan adalah deskriptif kualitatif yang digunakan untuk melakukan uji ketahanan tarik, perpanjangan putus dan uji biodegradabelitas 


\section{Hasil Penelitian}

Berdasarkan hasil penelitian pemanfaatan kombinasi kulit kacang dengan bonggol pisang dan biji nangka untuk pembuatan plastik biodegradable dengan penambahan gliserol diperoleh data hasil uji ketahanan tarik, perpanjangan putus, dan uji biodegradabelitas. Hasil uji ketahanan tarik, ketahanan sobek, dan uji biodegradabelitas adalah sebagai berikut.

\section{Kekuatan Tarik dan Perpanjangan Putus}

Tabel 1. Hasil rata-rata kekuatan tarik, perpanjangan putus pada plastik biodegradable dari kombinasi kulit kacang dengan bonggol pisang dan biji nangka dengan penambahan gliserol

\begin{tabular}{ccc}
\hline Perlakuan & Kekuatan Tarik $(\mathbf{N})$ & Perpanjangan Putus $(\mathbf{N})$ \\
\hline $\mathrm{K}_{1} \mathrm{G}_{1}$ & $1,38^{*}$ & 17,44 \#\# \\
$\mathrm{K}_{1} \mathrm{G}_{2}$ & 1,09 & 20,42 \\
$\mathrm{~K}_{1} \mathrm{G}_{3}$ & 0,85 & 22,33 \\
$\mathrm{~K}_{2} \mathrm{G}_{1}$ & 1,02 & 16,21 \\
$\mathrm{~K}_{2} \mathrm{G}_{2}$ & 0,81 & 19,32 \\
$\mathrm{~K}_{2} \mathrm{G}_{3}$ & $0,66 * *$ & 21,05 \# \\
\hline Keterangan: *: Kekuatan tarik yang paling kuat; \#: Perpanjangan putus paling kuat; **: Kekuatan tarik paling
\end{tabular}

\section{Plastik Biodegradable}

Tabel 2 Hasil uji biodegradabilitas pada plastik biodegradable dari kombinasi kulit kacang dengan bonggol pisang dan biji nangka dengan penambahan gliserol

\begin{tabular}{cccc}
\hline \multirow{2}{*}{ Konsentrasi Gliserol } & \multirow{2}{*}{ Perlakuan } & \multicolumn{2}{c}{ Fraksi Berat Residual (\%) } \\
\cline { 3 - 4 } & & Hari ke 0 & Hari ke 7 \\
\hline \multirow{2}{*}{$8 \mathrm{ml}$} & $\mathrm{K}_{1} \mathrm{G}_{3}$ & 100 & 90.38 \\
& $\mathrm{~K}_{2} \mathrm{G}_{3}$ & 100 & 78,25 \\
\multirow{2}{*}{$7 \mathrm{ml}$} & $\mathrm{K}_{1} \mathrm{G}_{2}$ & 100 & 86.25 \\
& $\mathrm{~K}_{2} \mathrm{G}_{2}$ & 100 & 67.47 \\
\multirow{2}{*}{$6 \mathrm{ml}$} & $\mathrm{K}_{1} \mathrm{G}_{1}$ & 100 & 82.35 \\
& $\mathrm{~K}_{2} \mathrm{G}_{1}$ & 100 & 58.84 \\
\hline
\end{tabular}

Berdasarkan hasil uji biodegradabilitas pada plastik biodegradable dari kombinasi kulit kacang dengan bonggol pisang dan biji nangka dengan penambahan gliserol menunjukkan pada hari ke-7 diperoleh data bahwa hasil perhitungan fraksi berat residual (\%) bioplastik dari kombinasi kulit kacang dan bonggol pisang dengan penambahan gliserol $8 \mathrm{ml}$ memiliki nilai rata-rata biodegradabilitas yang paling tinggi sedangkan bioplastik pada perlakuan kombinasi kulit kacang dan biji nangka dengan penambahan gliserol $6 \mathrm{ml}$ yang paling rendah .

\section{Pembahasan}

Berdasarkan hasil penelitian pengujian ketahanan tarik dan perpanjangan putus pada plastik biodegradable dari kombinasi kulit kacang dengan bonggol pisang dan biji nangka dengan penambahan gliserol sebagai berikut: 


\section{Ketahanan Tarik}

Adapun hasil ketahanan tarik dapat dilihat pada gambar 1 .

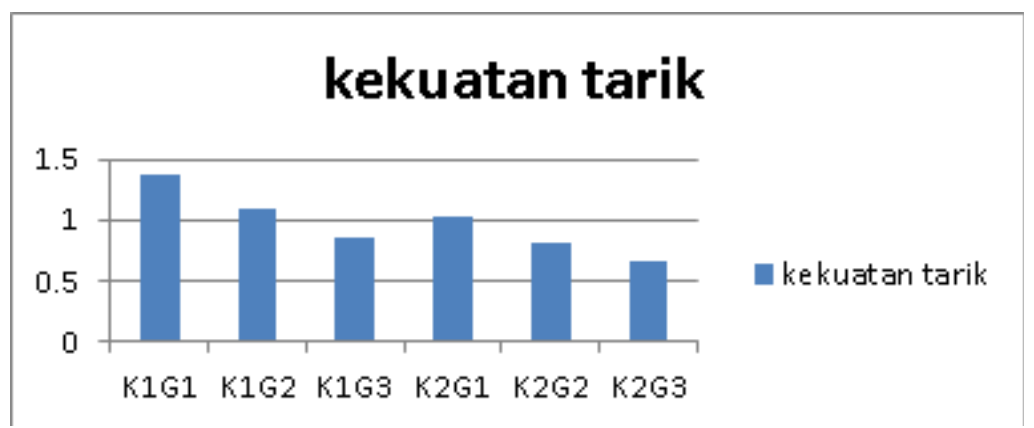

Gambar 1 Uji ketahanan tarik plastik

Berdasarkan hasil penelitian (Gambar 1) pada uji ketahanan tarik plastik biodegradable dari bahan baku kombinasi kulit kacang dengan bonggol pisang dan biji nangka dengan penambahan gliserol, diketahui bahwa ketahanan tarik paling kuat adalah pada perlakuan $\mathrm{K}_{1} \mathrm{G}_{1}$ yakni kombinasi kulit kacang dan bonggol pisang dengan gliserol 6\% dengan hasil $1.38 \mathrm{~N} / \mathrm{mm}^{2}$, diikuti dengan $\mathrm{K}_{1} \mathrm{G}_{2}(1.09 \mathrm{~N})$, $\mathrm{K}_{1} \mathrm{G}_{3}(0,85 \mathrm{~N}), \mathrm{K}_{2} \mathrm{G}_{1}(1.02 \mathrm{~N}), \mathrm{K}_{2} \mathrm{G}_{2}(0.81 \mathrm{~N})$, $\mathrm{K}_{2} \mathrm{G}_{3}(0.66 \mathrm{~N})$. Ketahanan tarik yang berbeda dikarenakan setiap perlakuan menggunakan bahan baku yang berbeda dan penambahan gliserin dengan persentase yang berbeda pula. Perlakuan yang memiliki nilai kekuatan tarik yang paling tinggi yaitu pada perlakuan $\mathrm{K}_{1} \mathrm{G}_{1}$ yakni bahan baku berupa kombinasi kulit kacang dan bonggol pisang dengan penambahan gliserol 6\%.

Pada gambar 1 diperlihatkan bahwa nilai kuat tarik pada diagram tersebut menunjukkan bahwa terjadi penurunan ketahana tarik seiring dengan semakin banyaknya jumlah gliserol yang digunakan. Hal tersebut dikarenakan gliserol yang berfungsi sebagai plasticizer berpengaruh pada ketahanan tarik, apabila persentasenya tidak optimum. Jumlah gliserol akan mempengaruhi ikatan hidrogen di antara polisakarida. Menurut Bourtoom (2008) kenaikan penambahan konsentrasi gliserol sebagai plasticizer dapat menyebabkan nilai kuat tarik semakin berkurang seiring dengan berkurangnya interaksi intermolekul. Berkurangnya interaksi tersebut dikarenakan adanya gliserol yang menyisip dan menghilangkan ikatan hidrogen di antara polisakarida. Apabila persentase giserol yang berfugsi sebagai plasticizer yang digunakan dalam jumlah yang besar maka akan menghasilkan mobilitas yang lebih besar terhadap makromolekul pati, sehingga kuat tarik bioplastik menurun.

Gliserol juga mempengaruhi terputusnya ikatan polisakarida, hal tersebut sesuai dengan hasil penelitian Muntohub dan Rahman (2011), bahwa penurunan nilai ketahanan tarik dikaitkan dengan semakin banyaknya jumlah gliserol karena adanya ikatan polisakarida yang diputus oleh gliserol. Sehingga menyebabkan ikatan dalam bioplastik semakin melemah.

Di samping persentase gliserol, bahan baku yang mengandung pati dan selulosa juga berpengaruh terhadap ketahanan tarik. Berdasarkan hasil penelitian Anggraini (2013) formulasi terbaik dihasilkan oleh campuran pati-aquades-gliserol 20\% menghasilkan plastik dengan nilai kuat tarik sebesar 58,83 Mpa. Bahan baku yang digunakan dalam penelitian ini berupa bonggol pisang dan biji nangka yang mengandung pati yang berbeda. Menurut Asni (2015) Kandungan pati di setiap varietas bonggol pisang berbeda, pada bonggol pisang mas mengandung $67,80 \%$ pati dan bonggol pisang kepok mengandung pati sebanyak 64,20\%. Sedang menurut Mukprasit (2004) pati biji buah nangka mengandung amilosa sebesar 39,23\%.

Ketahanan tarik pada plastik yang menggunakan kombinasi kacang tanah dan bonggol pisang lebih kuat dibandingkan dengan yang menggunakan kombinasi kacang tanah dan biji nangka karena pengaruh kandungan pati dan selulosa pada masing-masing bahan baku tersebut. Menurut Darni, et al (2010) selulosa dapat meningkatkan nilai kuat tarik pada titik tertentu. Selain itu pada sintesis plastik biodegradable tersebut terdapat ikatan hidrogen yang terjadi antara gugus 
hidroksil (O-H) dari pati dengan gugus hidroksil $(\mathrm{OH})$ dan karboksil $(\mathrm{COOH})$ dari selulosa. Ikatan tersebut mengakibatkan kekuatan material menjadi semakin meningkat (Septiosari, 2014).

\section{Perpanjangan Putus Plastik}

Adapun hasil ketahanan tarik dapat dilihat pada gambar 2 .

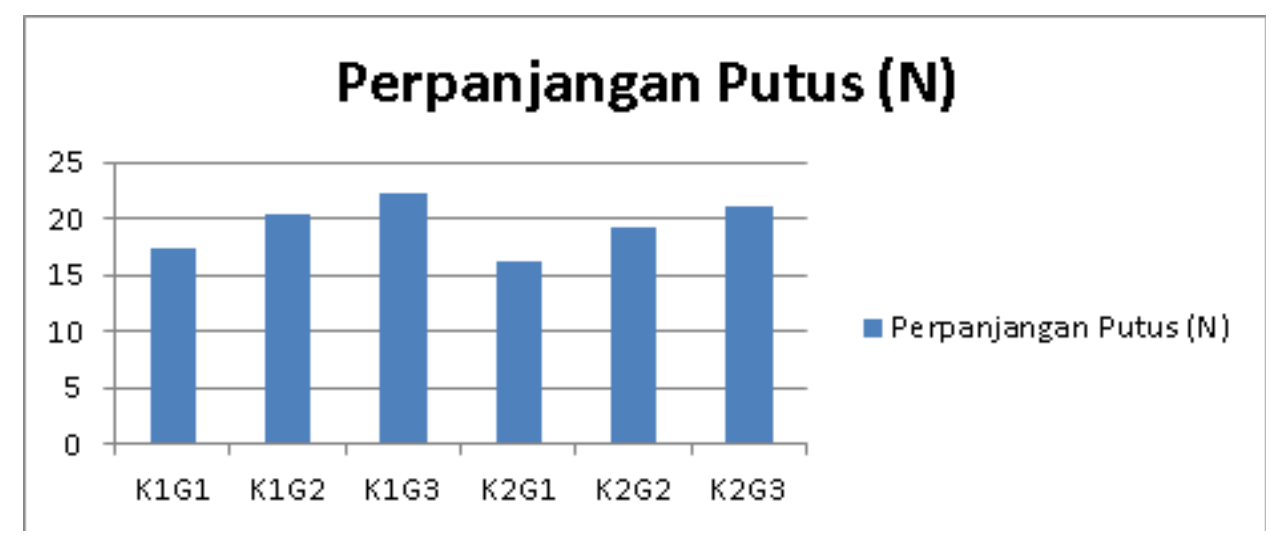

Gambar 2. Uji perpanjangan putus plastik

Berdasarkan hasil penelitian (Gambar 2) pada uji perpanjangan putus plastik biodegradable dari bahan baku kombinasi kulit kacang dengan bonggol pisang dan biji nangka dengan penambahan gliserol, diketahui bahwa ketahanan tarik paling kuat adalah pada perlakuan $\mathrm{K}_{1} \mathrm{G}_{3}$ yakni kombinasi kulit kacang dan bonggol pisang dengan gliserol 8\% dengan hasil $22.33 \mathrm{~N} / \mathrm{mm}^{2}$, diikuti dengan $\mathrm{K}_{2} \mathrm{G}_{3}(21.05$ $\mathrm{N}), \mathrm{K}_{1} \mathrm{G}_{2}(20.42 \mathrm{~N}), \mathrm{K}_{2} \mathrm{G}_{2}(19.32 \mathrm{~N}), \mathrm{K}_{1} \mathrm{G}_{1}(17.44$ $\mathrm{N}), \mathrm{K}_{2} \mathrm{G}_{1}(016.21 \mathrm{~N})$.

Perpanjangan putus plastik biodegradable yang berbeda dikarenakan masing-masing perlakuan menggunakan bahan baku yang berbeda dan penambahan gliserin dengan persentase yang berbeda pula. Tetapi yang berpengaruh sangat nyata volume gliserin yang berbeda. Semakin banyak volume gliserin yang digunakan, maka perpanjangan putus semakin tinggi. Pada penelitian ini perlakuan yang memiliki nilai kekuatan tarik yang paling tinggi yaitu pada perlakuan $\mathrm{K}_{1} \mathrm{G}_{3}$ yakni bahan baku berupa kombinasi kulit kacang dan bonggol pisang dengan penambahan gliserol $8 \%$, yakni $22.33 \mathrm{~N} / \mathrm{mm}^{2}$.

Pada gambar 2 diperlihatkan bahwa nilai perpanjangan putus plastik biodegradable pada diagram tersebut menunjukkan bahwa terjadi penurunan perpanjangan putus plastik biodegradable seiring dengan semakin sedikitnya volume gliserol yang digunakan dan jenis bahan baku yang digunakan. Dari hasil tersebut menunjukkan bahwa berpengaruh pada ketahanan tarik, apabila persentasenya tidak sesuai dengan jumlah yang dibutuhkan.

Gliserol yang berfungsi sebagai plasticizer akan mempengaruhi ikatan hidrogen di antara polisakarida. Selain itu gliserol dengan jumlah yang cukup akan memperbaiki dan mempercepat mekanisme plastisasi dengan matriks polimer sehingga menyebabkan hasil derajat elongasi menunjukkan kenaikan. Ketahanan tarik semakin elastis karena mobilitas molekuler rantai polimer seiring dengan penambahan volume yang sesuai.

Hal tersebut sesuai dengan hasil penelitian Darni (2010), bahwa gliserol merupakan agen yang dapat memperbaiki dan mempercepat mekanisme plastisasi dengan matriks polimer sehingga hasil derajat elongasi menunjukkan kenaikan seiring kenaikan gliserol. Dikuatkan juga dengan hasil penelitan Syamsu (2008), bahwa penambahan gliserol akan meningkatkan mobilitas molekuler rantai polimer yang ditunjukkan dengan semakin elastis bioplastik sehingga perpanjangan putus cenderung akan meningkat.

Gliserol yang ditambahkan dalam pembuatan plastik biodegradable mempengaruhi perpanjangan putus plastik menjadi semakin bertambah. Hal tersebut sesuai dengan hasil penelitian Anita (2013) pada penggunaan gliserol $2 \mathrm{ml}$ dan $4 \mathrm{ml}$ 
menunjukkan hasil perpanjangan putus semakin meningkat.

Konsentrasi perbandingan bahan juga menyebabkan penurunan ratio gliserol sebagai plasticizer terhadap pati, sehingga mengakibatkan penurunan elongasi plastik apabila terkena gaya, yang menyebabkan plastik mudah patah. Hal tersebut diartikan bahwa nilai perpanjangan putus berbanding terbalik dengan nilai kuat tarik.

Nilai kekuatan tarik dan perpanjangan putus tertinggi pada plastik biodegradable dari bonggol bahan baku kombinasi kulit kacang dengan bonggol pisang dan biji nangka dengan penambahan gliserol adalah $1.38 \mathrm{~N} / \mathrm{mm}^{2}$ dan 22,33\%, hal ini sudah sesuai dengan golongan moderate properties untuk nilai kekuatan tarik sebesar $1-10 \mathrm{Kg} / \mathrm{cm}^{2}$ dan nilai elongasi yaitu 10-20\% (Ani, 2010). Dalam penelitian ini nilai kekuatan tarik dan elongasi dari plastik ramah lingkungan (biodegradable) telah memenuhi golongan tersebut.

\section{Biodegradabilitas}

Berdasarkan hasil uji biodegradabilitas pada plastik biodegradable dari kombinasi kulit kacang dengan bonggol pisang dan biji nangka dengan penambahan gliserol dapat dilihat pada tabel 2. Pada hari ke-7 diperoleh data bahwa hasil perhitungan fraksi berat residual (\%) bioplastik dari kombinasi kulit kacang dan bonggol pisang dengan penambahan gliserol $8 \mathrm{ml}$ memiliki nilai rata-rata biodegradabilitas yang paling tinggi yaitu sebesar 90.38\% sedangkan bioplastik pada perlakuan kombinasi kulit kacang dan biji nangka dengan penambahan gliserol $6 \mathrm{ml}$ yang paling rendah yaitu sebesar 58,84\%.

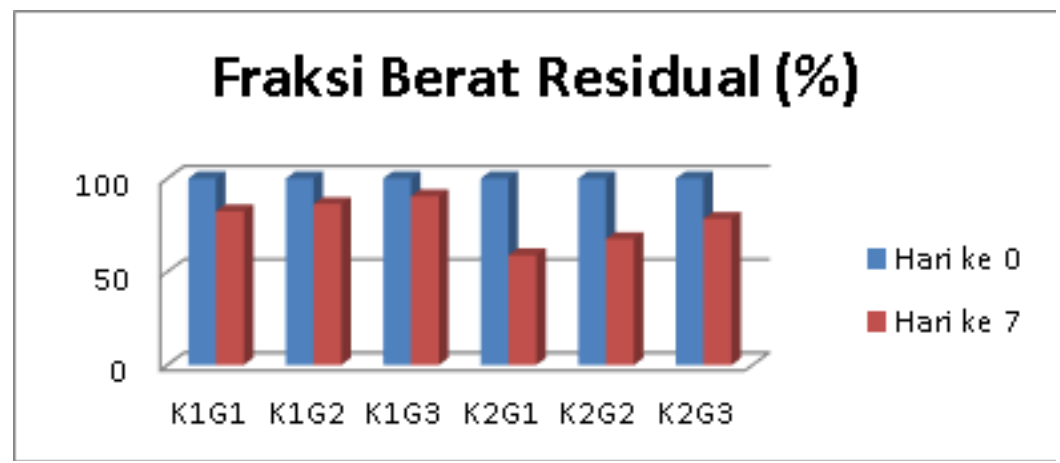

Gambar 3. Hasil biodegradabilitas plastik biodegradable dari bonggol pisang dan kulit kacang tanah dengan penambahan gliserol

Pada gambar 3 dapat dilihat bahwa kemampuan terdegradasi ditunjukkan dengan banyaknya berat plastik yang hilang. Berdasarkan hasil penelitian yang dilakukan dapat dilihat pada perlakuan kombinasi kulit kacang dan biji nangka dengan penambahan gliserol $6 \mathrm{ml}$ yang paling rendah yaitu sebesar $58,84 \%$. Persentase berat plastik yang berkurang akan semakin meningkat seiring bertambahnya jumlah gliserol. Pada kombinasi kulit kacang dan bonggol pisang dengan penambahan gliserol $8 \mathrm{ml}$ memiliki nilai biodegradable yang paling tinggi yaitu sebesar $90.38 \%$. Hal ini menunjukkan bahwa kemampuan degradasi plastik dipengaruhi oleh banyaknya gliserol yang digunakan. Semakin banyak gliserol yang digunakan maka akan meningkatkan kemampuan menyerap air sehingga plastik mudah terdegradasi.
Berdasarkan penelitian Pratiwi (2016), penggunaan gliserol $4 \mathrm{ml}$ menunjukkan kemampuan penyerapan air yang lebih besar dibandingkan dengan penggunaan gliserol $3 \mathrm{ml}$. Semakin banyak kandungan air dalam material maka akan semakin mudah plastik untuk terdegradasi.

Selain gliserol, selulosa juga dapat meningkatkan kemampuan terdegradasi pada plastik karena mempunyai gugus hidroksil $\mathrm{OH}$ yang menginisiasi reaksi hidrolisis setelah mengabsorbsi air dalam tanah, juga karena aktivitas mikroba yang berada di dalam tanah. Pati yang juga mempunyai gugus $\mathrm{OH}$ akan terdekomposisi bersama selulosa menjadi potongan-potongan kecil hingga menghilang di dalam tanah. Degradasi akan terjadi karena proses kerusakan atau penurunan mutu karena terputusnya ikatan rantai pada polimer (Marhamah, 2008). 


\section{Simpulan}

Berdasarkan data dan pembahasan dapat diambil kesimpulan sebagai berikut:

1. Ada perbedaan ketahanan tarik dan perpanjangan putus plastik biodegradable dari kulit kacang dengan bonggol pisang dan biji nangka dengan penambahan gliserol. Ketahanan tarik paling kuat adalah pada perlakuan kombinasi kulit kacang dan bonggol pisang dengan gliserol 6\% dengan hasil $1.38 \mathrm{~N} / \mathrm{mm}^{2}$, ketahanan tarik paling rendah pada perlakuan kombinasi kulit kacang dan biji nangka dengan gliserol $8 \%$ dengan hasil $0.66 \mathrm{~N} / \mathrm{mm}^{2}$. Sedangkan perpanjangan putus paling tinggi adalah pada perlakuan kombinasi kulit kacang dan bonggol pisang dengan gliserol 8\% dengan hasil $21.05 \mathrm{~N} / \mathrm{mm}^{2}$, perpanjangan putus paling rendah pada perlakuan kombinasi kulit kacang dan biji nangka dengan gliserol $6 \%$ dengan hasil $17.44 \mathrm{~N} / \mathrm{mm}^{2}$.

2. Ada perbedaan hasil uji biodegradabilitas pada plastik biodegradable dari kombinasi kulit kacang dengan bonggol pisang dan biji nangka dengan penambahan gliserol. Pada perlakuan kombinasi kulit kacang dan bonggol pisang dengan penambahan gliserol $8 \mathrm{ml}$ memiliki nilai rata-rata biodegradabilitas yang paling tinggi yaitu sebesar $90.38 \%$ sedangkan bioplastik pada perlakuan kombinasi kulit kacang dan biji nangka dengan penambahan gliserol $6 \mathrm{ml}$ yang paling rendah yaitu sebesar $58,84 \%$.

\section{Daftar Pustaka}

Anggraini, Fetty, Latifah, dan Siti Sundari Miswadi. 2013. Aplikasi Plasticizer Gliserol pada Pembuatan Plastik Biodegradable dari Biji Nangka. Indonesian Journal of Chemical Science. Vol. 2, No. 3.

Ani, P. 2010. Analisis kuat Tarik dan Elongasi Plastik Kitosan terplastisasi Sorbitol. Yogyakarta: Institut Sains \& Teknologi AKPRIND.

Anita, Z; Akbar, F; dan Harahap, H. 2013. Pengaruh Penambahan Gliserol Terhadap Sifat Mekanik Film Plastik Biodegradasi dari Pati Kulit Singkong. Jurnal Teknik Kimia USU. Volume 2 (02).

Asngad. A, Siti. I.N, Siska. S. 2016. Pemanfaatan Kulit Kacang dan Bulu Ayam sebagai Bahan Alternatif Pembuatan Kertas Melalui Chemical Pulping dengan Menggunakan $\mathrm{NaOH}$ dan Cao. Bioeksperimen. Vol. 2, No. 1.

Asni, W. 2015. Analisis Kandungan Pati pada Bonggol Pisang. Aceh: Universitas Syiah Kuala.

Bourtoom, T. 2008. Edible Films and Coatings: Characteristics and Propertis. International Food Reserch Journal.Vol 15 (03). Hal: 1-12.

Darni, Yuli Dan Herti Utami. 2010. Studi Pembuatan dan Karakteristik Sifat Mekanik dan Hidrofobisitas Bioplastik dari Pati Sorgum. Jurnal Rekayasa Kimia dan Lingkungan. Vol. 7, No. 4, Hal. 190-195, 2010 ISSN 1412-5064

Dahlan dan Darmansyah. 2011. Pemanfaatan Kulit Kacang Tanah sebagai Pupuk Organik pada Kacang Tanah (Utilization Of Peanut Shell As Organic Fertilizer On Peanut Crop). Jurnal Agrisistem. Vol.7.No.2.

Eko, Debi dan Danar Kusananda. 2010. Pembuatan Biobriket dari Campuran Kulit Kacang dan Serbuk Gergaji sebagai Bahan Bakar Alternatif. ITS. Surabaya

Fachr, A. Rasyidi; dan Sartika, Adhestya. 2012. Pemanfaatan Limbah Kulit Udang dan Limbah Kulit Ari Singkong sebagai Bahan Baku Pembuatan Plastik Biodegradable”. Jurnal Teknik Kimia. Vol 18 (3). Page 1-9.

Kruiskamp, PH; et al. 2001. The Influence of Plasticiser on Molecular Organisation in Dry Amylopectin Measured by Differential Scanning Calorimetry and Solid State Nuclear

18-Pemanfaatan Kombinasi Kulit... 
Magnetic Resonance Spectroscopy. Journal Industrial Microbiology \& Biotechnolog. Vol 26. Page: 90-93.

Marhamah. 2008. Biodegradasi Plasticizer Poligliserol Asetat (PGA) dan Dioktil Ftalat (DOP) dalam Matrik Polivinil Klorida (PVC) dan Toksisitasnya terhadap Pertumbuhan Mikroba. Tesis. Sumatera Utara: USU.

Mukprasirt, A. And Sajjaanantakul, K., 2004. Physico-chemical Propertis of Flour and Starch from Jackfruit Seed (Arthocarpus heterophyllusLam). Compared with Modified Starches. International Journal of Food Science and Technology. Vol 39, 271-276.

Murni, R, dkk. 2008. Pemanfaatan Limbah sebagai Bahan Pakan Ternak. Laboratorium Makanan Ternak Fakultas Peternakan Universitas Jambi. Jambi.

Paramawati R. 2001. Kajian Fisik dan Mekanik Terhadap Karakteristik Film Kemasan Organik Dari Zein Jagung. Disertasi. Bogor: Program Pascasarjana, Institut Pertanian Bogor.

Pratiwi, Ricka Indria; Saleh, Chairul; dan Tarigan, Daniel. 2016. Pemanfaatan Bonggol Pisang Kepok (Musa paradisiaca. L) sebagai Bahan Pembuatan Plastik yang Mudah Terdegradasi dengan Penambahan Plasticizer Gliserol. Jurnal Atomatik. Vol 01(2). Hal: 104-106.

Septiosari. Arum. 2014. Pembuatan dan Karakteristik Bioplastik Limbah Biji Mangga dengan Penambahan Selulosa dan Gliserol. Indonesian Journal of Chemical Science. Vol. 3, No. 2.

Syamsu, K, dkk. 2008. Karakteristik Biolastik Poli- $\beta$-Hidroksialkanoat yang Dihaslikan oleh Ralstonia eutropha pada Substrat Hidrosilat Pati Sagu dengan Pemlastis Isopropil Palmitat. Jurnal Teknologi Pertanian. Universitas Mulawarman, ISSN 1858-2419. Vol3 (02).Samarinda. 